\title{
, \\ COVID-19 and Construction: Impact Analysis on Construction Performance during Two Infection Waves in Victoria, Australia
}

\author{
James Bell ${ }^{1}$, Henry Chan ${ }^{2}$, Michael Chan ${ }^{3}$ and Sungkon Moon ${ }^{4, *}$ \\ 1 Noble Trading Manufacturing Pty Ltd., Gembrook, VIC 3783, Australia; jamesbell328@gmail.com \\ 2 Department of Civil and Construction Engineering, Swinburne University of Technology, \\ Melbourne, VIC 3122, Australia; 100600099@student.swin.edu.au \\ 3 Department of Transport, Victoria State Government, Melbourne, VIC 3151, Australia; mchan262@gmail.com \\ 4 Department of Civil Systems Engineering, College of Engineering, Ajou University, Suwon 16499, Korea \\ * Correspondence: sungkon.moon@gmail.com
}

check for updates

Citation: Bell, J.; Chan, H.; Chan, M.; Moon, S. COVID-19 and

Construction: Impact Analysis on Construction Performance during Two Infection Waves in Victoria, Australia. Sustainability 2022, 14, 2580. https://doi.org/10.3390/su14052580

Academic Editor: Antonio Caggiano

Received: 10 January 2022

Accepted: 19 February 2022

Published: 23 February 2022

Publisher's Note: MDPI stays neutral with regard to jurisdictional claims in published maps and institutional affiliations.

Copyright: () 2022 by the authors Licensee MDPI, Basel, Switzerland. This article is an open access article distributed under the terms and conditions of the Creative Commons Attribution (CC BY) license (https:// creativecommons.org/licenses/by/ $4.0 /)$.

\begin{abstract}
This research outlines the fluctuation in confirmed active cases of coronavirus disease 2019 (COVID-19), as related to the changes in the Victoria state government's rules and restrictions. Further, this study examines the impact of government restrictions on the performance of construction in Victoria, Australia. The data analyses in this paper identify the specific effects on industrial production, during the different lockdown stages, in three local construction companies. Companies were selected from different points along the supply chain. Company A is a supplier involved in the manufacturing of structural steel. Company B conducts logistics and procurement. Company $\mathrm{C}$ is a construction engineering business specializing in foundations. After reviewing relevant case studies and theories, data analyses were developed in collaboration with these companies. The results revealed that the impact of restrictions on the workers on individual construction projects was not significant. Stage 4 restrictions (Victoria's highest lockdown level) significantly impacted overall income by limiting construction to only servicing essential infrastructure or essential businesses. The novel contribution of this study is the data analysis outcome for Victoria, where a high level of restrictions were experienced, such as curfew and enforced isolation at home, relative to other countries. In 2021 and 2022 (omicron variant dominated), Victoria was again at the brink of an infection wave, which showed a similar pattern to July 2020, and endured the world's longest COVID19 lockdown. The research findings contribute to the body of knowledge by providing empirical data analysis of each company, representing the economic impact of ordinary small and medium enterprises (SMEs) in construction.
\end{abstract}

Keywords: COVID-19; pandemic; impact analysis; COVID-19 and construction; Victoria; Australia

\section{Introduction}

In 2019, a virus unexpectedly mutated, became transmissible to humans, and subsequently spread worldwide. It was named coronavirus disease 2019 (COVID-19) [1]. At the beginning of 2020, the pandemic's global threat increased, and, in response, Australian industries made widescale changes because they "anticipated a 39\% decline in construction business due to government restrictions" [2], indicating a corresponding change in the construction industry's performance.

The construction industry is a significant pillar of Australia's economy [3]. It generates 360 billion Australian dollars (AUD) in revenue, approximately $7.7 \%$ of the Australian gross domestic product (GDP). The absence of an effective and ever-expanding construction industry would lead to a diminished response to the population's needs, related to population growth and continually changing public demand. As the pandemic grew out of control, governments were forced to implement strategies to diminish infection rates [4]. The state of Victoria experienced two waves of high community infection in March and July 2020, when the state government had to implement lockdown restrictions to suppress 
transmission [5]. In August 2020, at the peak of the second wave, new case numbers in Victoria reached a 14-day average of over 450, and Victoria recorded 725 new cases on 5 August $[5,6]$. Due to these high case numbers, freedom of movement was restricted, in order to reduce transmission and suppress the spread [4]. Coinciding with these decisions, the loss of jobs in Australian construction resulted in an annual shrinkage of 13.9 billion AUD [7]. Non-essential workers were required to remain at home, and businesses ceased operation; only those deemed 'essential' could continue operating.

Meanwhile, the sector continued to operate, since the construction industry contributes a significant proportion of GDP and workforce, and the government did not want to cause a wave of damage litigations. McKenzie [8] presented a report stating, "The Government is understandably reluctant to place restrictions on the construction industry ... restrictions would have a significant impact on the 1.2 million people $(9.1 \%$ of the Australian workforce) employed ... The Australian Financial Review has reported the shutting down of building sites could spark monthly claims of up to AUD two billion between Contractors and Principals".

Even though construction continued during the restrictions, this was not "business as usual". According to WorkSafe Victoria [9], operations were strained, due to diminished income and reduced freedom to conduct on-site activities. Additionally, as common cold symptoms were similar to the virus, individuals were frequently absent from work. According to the latest statistics from Direct Health Solutions, absenteeism, across all sectors of industry, increased by 10\% in March 2020 [10]. Nevertheless, the Australian economy and jobs in the construction sector depend on the industry's success, and with the "country's reliance on this sector" [11], it is paramount that the sector remains resilient.

Given the global situation, this paper focuses on case studies at the organizational level, in order to empirically identify the effects on construction companies by comparing fluctuations in Victoria with the countermeasures implemented by the Victoria state government. The goal of this study is to assess how the pandemic has affected Victoria's construction industry. Victoria is one of few regions where the state government implements high restriction levels to suppress the spread of infection. Restrictions can include a curfew, enforced isolation at home, forced business closures, and a ' $5 \mathrm{~km}$ rule' (people must stay within $5 \mathrm{~km}$ of their home) [12]. In addition, in mid-2021, Victoria was at the brink of another wave of infection that showed a similar pattern to that of July 2020 [13]. Thus, analyzing the 2020 Victoria cases is expected to generate novel findings, due to the distinct circumstances.

It is necessary to investigate the specific cause of observed changes to understand the situation better and prepare a more refined future response. Furthermore, if areas of major impact on business performance are identified, proactive measures to resist future impact can be taken. Finally, it is crucial to analyze the near-future prospects of construction businesses, given their likely position after this crisis.

\section{Reviews and Background}

\subsection{Victoria State Government's Response for Public Health and Safety}

This section presents the Victoria state government's response to COVID-19 in 2020. The scope of the study includes mid-2020, when Victoria experienced the second wave of cases, and high levels of restrictions were imposed throughout the state. This study aims to discover the effect of these measures on the construction industry. Victoria faced the initial outbreak with the rest of the country; however, just as restrictions were being eased, a second wave became evident, worse than the first. As shown in Figure 1, the waves in March and July 2020 differently threatened public health and required varying levels of government response [4]. Throughout 2020, the Victoria state government set four stages of restrictions, following state of emergency announcements during the initial outbreak, and later a state of disaster during the occurrence. 


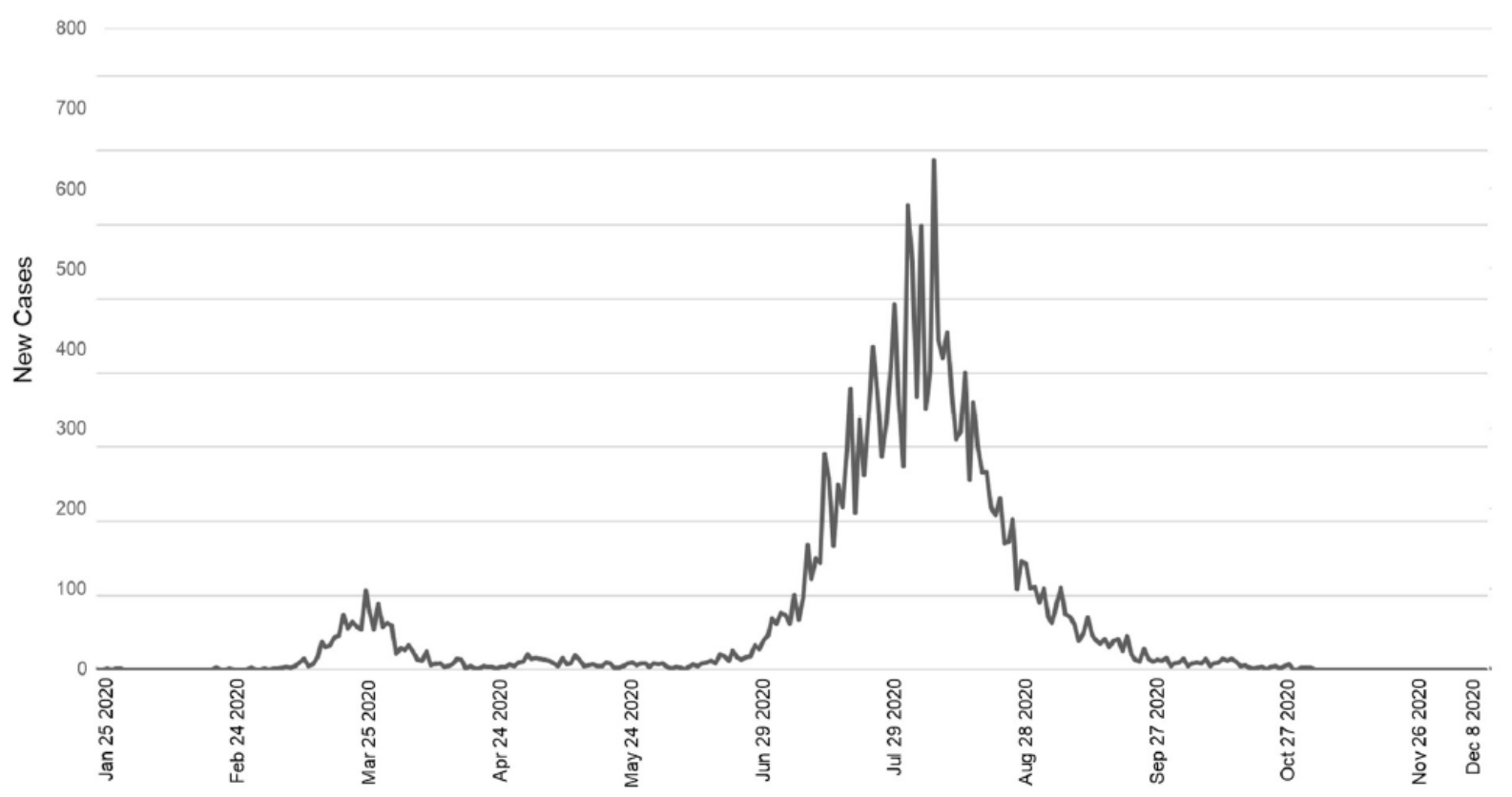

Figure 1. Victoria's daily new cases [4].

Victoria state was the worst affected in Australia, with a high community transmission rate [14]. As a result, more stringent lockdown restrictions and public health law enforcement were initiated to diminish the virus's circulation and combat its spread. Between March and September 2020, increasingly stricter rules were imposed in Victoria. On 16 March 2020, the Minister for Health declared a "state of emergency throughout the state of Victoria" [15]. The Premier described this declaration as necessary to provide the chief health officer with the power to enforce 14-day isolation requirements for all travelers entering Australia. The measure was initially active for a four-week legislative period but extended an unprecedented five times [15,16].

A myriad of government responses occurred during March. In their report, Beck and Hensher [17] detailed that a strict $4 \mathrm{~m} 2$ social distancing rule was imposed. In addition, international travel was banned, as later in March, Australia closed its borders, people arriving in Australia were required to undergo a 14-day quarantine, and most states closed their borders for domestic travel. Financial support was implemented to combat a suffering economic climate, with the Reserve Bank of Australia (RBA) reducing the cash rate to a record low of $0.25 \%$ [18]. Federal and state leaders contributed to a combined AUD 17.6 billion assistance package; later, a further AUD 66 billion assistance package was announced (primarily through the JobSeeker policy), as Stage 1 restrictions were implemented $[19,20]$.

Stage 1 restrictions were introduced on 22 March 2020, including a $1.5 \mathrm{~m}$ social distancing regulation, and expected to last for a minimum of six months [21]. A few days after the initial announcement, Stage 2 measures with further restrictions on non-essential social gatherings took effect on 25 March 2020 [21]. In essence, elective activities that could be avoided were restricted. In addition to the businesses previously mentioned, cafes, beauty therapy, spas, nightclubs, casinos, strip clubs, health clubs, swimming pools, and libraries were closed. Open-house inspections were conducted by private appointment only, and appointments with hairdressers and barbers were restricted to a maximum of 30 min, with the "four square meters" rule applied.

As the number of cases grew sharply, with around 350 cases per day reported in Victoria, the Australian government announced the start of Stage 3 restrictions [22]. These restrictions stipulated five reasons that Australians should be outside of their homes: shopping for daily supplies, medical purposes, exercise within $5 \mathrm{~km}$ of home (while observing social distancing rules), necessary visits to friends and family, and accessing 
essential services, such as telecom, pharmacy, supermarket, and banking. Up to 31 May 31 2020, the total number of COVID-19 confirmed cases in Victoria was 1649, including 19 deaths [23]. However, 1547 people recovered and six people remained in hospital, with two in intensive care [23]. Construction was considered an essential service [24], so construction sites continued to operate, but workers were required to follow social distancing rules and hygiene guidelines, while maintaining the health and safety practices enforced by the Victoria state government.

During Stage 4 restrictions, there were very few reasons to be outside: shopping for food and essential items, care and caregiving, daily exercise, and work. However, shopping for food and essential items was required to be conducted within $5 \mathrm{~km}$ of home, and exercise was limited to a maximum of one hour per day [25]. In addition, a curfew was enforced from 8 pm to 5 am, with Victorians not allowed to leave their homes, except for work, essential health care, or safety reasons; workers were required to provide a work permit to prove that they worked during those times. Since the construction sector continued to be considered an essential industry during the Stage 4 lockdown, construction workers and suppliers were still eligible to go to building sites. However, construction sites required a regularly updated, high-risk COVID-19-safe plan and issued work permits to all on-site workers, not allowing more than one worker per four square meters and limiting workers' movement between multiple sites.

As the Stage 4 restrictions continued, cases slowly decreased. On 6 September, the Victoria state government introduced "Victoria's roadmap for reopening" [26]. On 13 September, they eased the curfew to 9 pm to 5 am; by 28 September, the curfew ended [27]. At the time of writing, the situation is still changing rapidly, due to a series of new variants, especially the omicron variant, which is reported to cause milder disease. Many countries, including Australia, are responding to the threat posed by this new variant [28]. The number of new active cases is sharply increasing, by comparison with the previous waves, but the number of lives lost is not increasing, and there is still sufficient capacity in intensive care units (ICU) [29]. Therefore, this study needs to focus on 2020, when the impact of COVID-19 was greater.

\subsection{Previous Research Works: The Impact of COVID-19 on Construction}

Table 1 lists the previous works relevant to the research focus of this paper. Halpin suggested the managerial construction levels, shown in the table's left column [30]. A series of sequences were related to these levels and construction [30,31]. The literature in the table was published in 2021, but the crucial stages of the pandemic started in early 2020. Among seven articles, four focused on the organizational level. For example, Wang et al. [32] presented work in May 2021, focusing on organizational citizenship behavior in emergency construction megaprojects. They developed four categories for hypotheses to evaluate emergency megaproject citizenship behavior (EMCB). Tan et al. [33] also presented a case study of a modular emergency building in Wuhan, China (i.e., Huoshenshan Hospital). This study focused on a management strategy and method, for the design for manufacture and assembly (DfMA).

Kim et al. [37] published work with scenario-based simulations. They developed three scenarios of curtain-wall operations and measured workdays, calendar days, total cost, and liquidated damages, which included the quantified effect of COVID-19 on pre- and post-COVID-19 curtain-wall operations. Pirzadeh and Lingard [39] conducted a survey related to three construction projects. Combining the survey and qualitative analysis, they concluded the effect on individual workers' health and well-being. 
Table 1. Summary of previous works.

\begin{tabular}{|c|c|c|c|c|}
\hline Managerial Levels & Summarized Findings & $\begin{array}{l}\text { Method and Data } \\
\text { Sources }\end{array}$ & References & Region \\
\hline Organizational & $\begin{array}{l}\text { COVID-19 had positive effect on the } \\
\text { six dimensions EMCB } \\
\text { (1) }\end{array}$ & $\begin{array}{l}\text { Questionnaire and } \\
\text { analysis of two cases }\end{array}$ & [32] & China \\
\hline Organizational & $\begin{array}{l}\text { Adjustment to comply with relevant } \\
\text { requirement; the pandemic has } \\
\text { impacts on construction }\end{array}$ & $\begin{array}{l}\text { Reviews on various } \\
\text { resources }\end{array}$ & [34] & United States \\
\hline Organizational & $\begin{array}{l}\text { Challenges by COVID-19 include } \\
\text { procurement and potential disputes, } \\
\text { while new opportunities include } \\
\text { lower interest rates and } \\
\text { medical-constructions }\end{array}$ & Telephone interviews & [35] & Unite States \\
\hline Organizational & $\begin{array}{l}\text { COVID-19 may account for the } \\
\text { fluctuations of construction } \\
\text { cost index }\end{array}$ & $\begin{array}{l}\text { Statistical analysis by } \\
\text { linear forecasting } \\
\text { models }\end{array}$ & {$[36]$} & Unite States \\
\hline Project-Activity & - & - & - & - \\
\hline Operation & $\begin{array}{l}\text { COVID-19 guideline increases } \\
\text { workdays and costs }\end{array}$ & $\begin{array}{l}\text { Scenarios-based } \\
\text { Simulation }\end{array}$ & [37] & South Korea \\
\hline Process & $\begin{array}{l}\text { COVID- } 19 \text { may place more pressure } \\
\text { on work-life boundaries }\end{array}$ & $\begin{array}{l}\text { Interviews with } \\
\text { construction } \\
\text { professionals }\end{array}$ & [38] & Australia \\
\hline Work Task & $\begin{array}{l}\text { Work from home has a positive } \\
\text { effect of workers' family and work } \\
\text { satisfaction }\end{array}$ & $\begin{array}{l}\text { Survey from three } \\
\text { construction projects }\end{array}$ & [39] & Australia \\
\hline
\end{tabular}

(1) EMCB: Emergency megaproject citizenship behavior; six dimensions: compliance behavior, contingent collaboration behavior, conscientiousness behavior, harmonious relationship maintenance, initiative behavior, and dedication behavior.

There is still a need for research at the project-activity level of managerial analysis in examining the recent findings. Therefore, this presented work gathers project-based data to analyze the effect of COVID-19 on construction performance. The operation level presents the general practical approach, and the project level of the analysis presents reactive scientific evidence to prepare future research. In addition, the presented study presents work to analyze company-based data sets directly, filling a gap in on-site data analysis and expecting practical findings. Two previous works, based on Australian cases, did not study the industrial construction aspect. The following section presents the details of the research scope and method.

\section{Research Theories, Method and Scope}

The case studies in this paper utilize a quantitative method, based on a numerical fluctuation analysis. In addition, a qualitative method (interviews) is used to obtain a generalizable understanding of the quantitative analysis [40]. The study consists of data collection and analysis; the data sets consist of quantitative numerical and qualitative interview data [41]. The integrated method aims to present information to advance construction practices against the COVID-19 situation in Victoria, Australia. The research includes identifying measurable effects of COVID-19-related lockdowns and enforced regulation on construction performance. In addition, this regional study (Victoria State) will reveal findings for application to other areas experiencing similar situations.

This study's initial question is whether Victoria's construction practices are affected by the Victoria state government's lockdown plan, even though construction is recognized as an essential business during enforced lockdowns. It is generally assumed that stricter administrative regulations build a visible path, affecting operational decisions and actions [42]. Therefore, data were gathered for individual companies in Victoria, aiming to validate the 
impact of the government regulations. Although it was evident that the overall macro-level of the indexes showed a downward tendency, the case studies in this paper are designed to conduct operational level analyses of individual companies. This micro-level analysis presents direct observations on the companies' performance to enhance cross-referencing patterns [43].

Carefully selecting the case study's companies is critical to prevent bias in the findings $[41,44]$. In this study, construction companies were selected based on reviewing several criteria, such as the company size, regional area of current projects, and availability of information from past projects [45]. It is reported that a large number of small and medium enterprises (SMEs) have failed, due to the COVID-19 crisis [46], so the research's data collection focused on small to medium-sized construction companies. Finally, three local companies were selected along the supply chain, i.e., a supplier, procurement company, and on-site constructor, in order to achieve an overview of COVID-19's impact on the construction supply chain, according to Victoria state's measures and regulations.

The analysis utilized the production data of three companies from 2018 to the present and consisted of two steps: cross- and within-case analysis [41]. First, a cross-case analysis compared three companies to explore fluctuations under the same conditional situations. Next, a within-case analysis presented each company's details by further discussion and interviews with company workers. The information was graphically presented to assess whether the effects occurred during the expected period and correlated with introduced restrictions. In addition, a supplemental survey questionnaire was given to the three companies' directors, to gain context in the within-case analysis, and their responses are included in this paper, where applicable.

The study analyzed information from January 2018 to October 2020, when Victoria experienced two waves of infection and corresponding restrictions from the Victoria state government. The projects conducted during this timeframe were assessed, and pertinent information was collected. The results were then compiled. However, the collected data were not evenly distributed and varied between projects. As a result, the information was divided into financial quarters, to provide discrete periods for assessing production factors and observing seasonal fluctuations.

Notably, there were periods where no data existed for a particular quarter, due to a lull in business, a project spanning an extended period, or because the information was not available for analysis. Furthermore, as the information was relative, rates or ratios of values for different types of production and differences in job size, such as profit margins, were diminished in fractional form. Finally, the results from 2020 were compared against the baseline in previous years, and the behaviors were interpreted in the context of a pandemic and the impact of Victoria state government restrictions on production factors.

\section{Case Data Analysis}

This report focuses on the analysis of observational data. Considering all the variables inherent in construction and filtering this to find those factors common to the three companies, a list of data types was developed that will be useful for performance comparisons. Past and present data, concerning the details of construction projects, such as labor and time, were included to assess productivity levels. After viewing a tabulated list of the data they needed to provide, companies A, B, and C consented to their involvement. However, they preferred to remain anonymous, given the sensitivity of the information. The production date and analysis are presented in this section. Companies A, B, and C consented to their involvement, upon viewing the list of required data in a table to be populated. All three companies are located and head-quartered in Victoria, and most of their projects are in the metropolitan area of Melbourne. This area is exactly the region where the Victoria state government's rules apply. The companies are small- to medium-sized enterprises (SMEs), which means that the total number of employees is less than 200. We selected SME companies since these are representative of $92.0 \%$ of all businesses in Australia [47]. 
Three companies along the supply chain were selected, to observe trends in the affected industry comprehensively. However, the companies requested anonymity, given the sensitivity of the information that they were asked to provide. Company A manufactures structural steel and often uses Company B as a supplier. Since Company A supplies structural steel to its customers, it is categorized as a supplier in the construction supply chain. Company B manages the logistics, installation, and erection of structural steel systems and reconfigures or optimizes existing storage systems, predominantly for factories and warehouse clients. Company B is an intermediary between the supplier and customer, as it provides logistics and procurement services between the manufacturer and the construction site. Company $\mathrm{C}$ is a foundations specialist in residential and commercial underpinnings, screw piling, and bored piers. Company $\mathrm{C}$ represents the final customer in the construction industry for both companies A and B. The suppliers for company C provide either concrete or fabricating steel. A list of data types was developed using past and present construction project data, in order to assess production levels of these three companies, such as labor and time factors.

\subsection{Time Dedicated (per Week) to Projects}

Traditionally, a construction company can estimate, with relative certainty, the quantity of work required to complete a project. This estimation may be formed by a time-based index, such as man-hours, days, and weeks. However, the crucial factor is that the time required per week should be relatively consistent across the assessed period. A consistent routine helps to plan the overall supply-and-demand of resources, which eventually affects the performance of an entire company in the mid- to long-term [48]. Deviations in resource allocation can lead to an increase in required working hours and result in extra cost for the project. The reality of this factor is displayed in Figure 2 below.

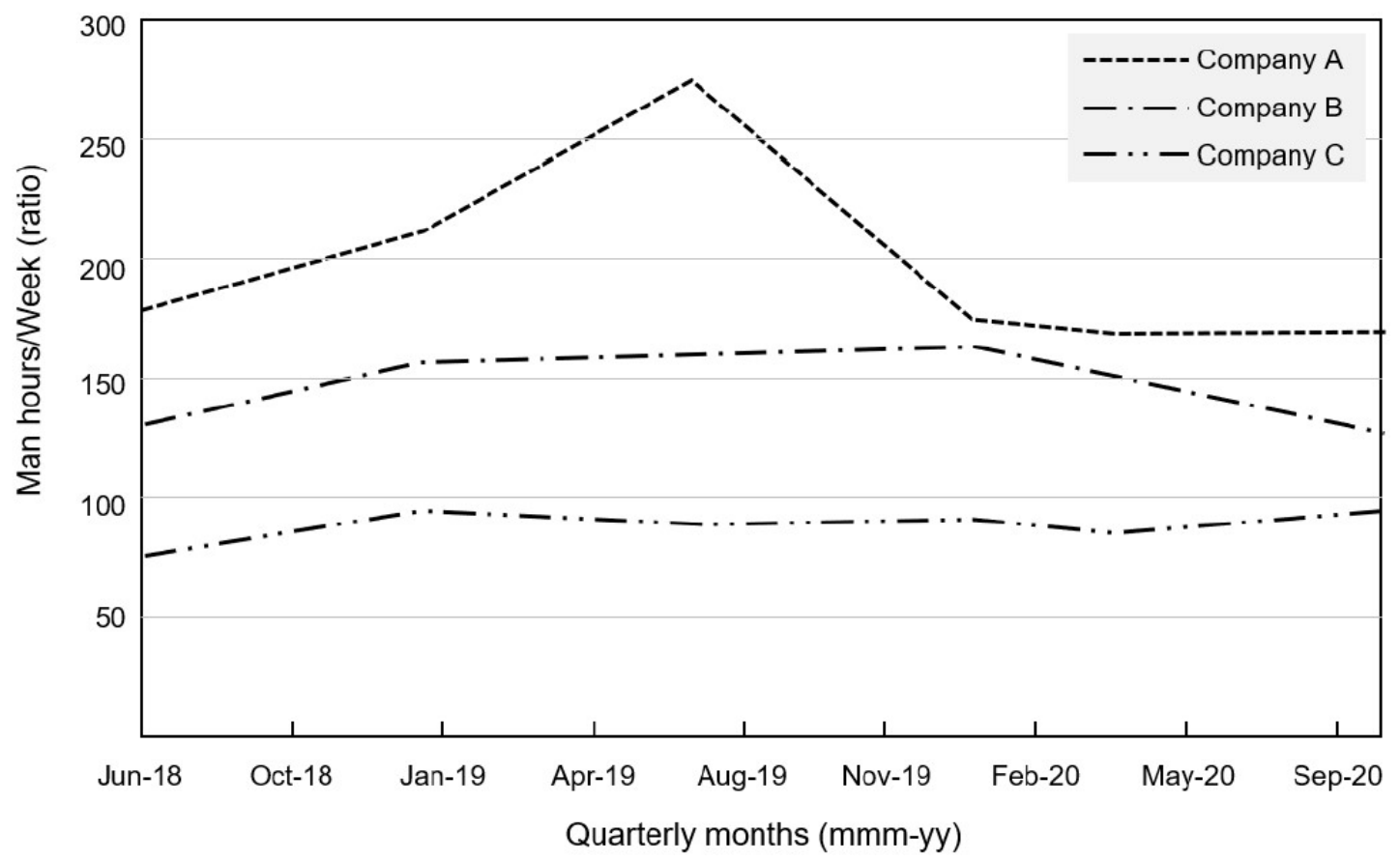

Figure 2. Time dedicated per week to projects from companies A/B/C.

Company C showed a slight fluctuation during 2020 in the number of person-hours spent on-site per week. When the questionnaire specifically asked about this point, the response was, "No, I have not seen any changes in production". This response was reasonably consistent with the data. A slight downward trend was seen at the beginning of 2019. However, the scale of work undertaken in 2020 was much larger than company C's 
typical projects. Therefore, the variation was smaller than expected, and the change could be omitted.

Company B's results were not very useful because most of the baseline in 2019 showed a steep incline and then settled back to the expected usual level. According to its report, company B was involved in a large-scale interstate project that required particular attention. As a result, staff needed to work overtime, and extra subcontractors were required. However, during 2020, a steady level was maintained, so it was assumed that the time required to conduct the company's usual activities did not change significantly.

A notable downturn was seen in company A from March 2020. When interviewed, a company accountant mentioned, "From January 2018 to March 2020, the average staff level was 12 full-time equivalents (FTEs) in 2018, 14 FTEs in 2019, and has dropped to 9 FTEs since March 2020 ... reduced by approximately $20 \%$. Some were elective, and some forced". This statement appeared consistent, as the drop in laborers accounted for the variation in the amount of labor per week. From this analysis, there was little evidence that the pandemic, and subsequent restrictions, had much of an effect on the projects' time input. However, company A's reduced workload could have influenced a change in workforce levels.

\subsection{Monetary Value of Work Achieved}

By establishing the ratio of a project's person-hours per dollar, it was possible to compare the number of hours required to complete projects similar in size and activity. Figure 3 shows that Company B remained steady, even during the pandemic, apart from minor fluctuations. Company A had been on a consistent downward path from the beginning of 2018. However, there was not a comparatively significant decline in 2020, compared with the earlier trajectory, and it remained relatively consistent with its typical behavior. In addition, there were consistent drops in person-hours, but project values were consistent, demonstrating no significant influence, as expected for 2020.

As company $\mathrm{C}$ showed fluctuations throughout the data, a baseline was challenging to establish, but an approximately level trend for 2020 (Figure 3a) indicated a consistent ratio for these two quantities. A comparison of the results of Figure $3 b, c$ showed consistent growth in person-hours over the years, and steeper growth in project value, implying that Figure 3a should, in theory, show a decline in 2020. However, the figures were consistent from the end of 2019 to date, indicating that no significant change in production was seen.

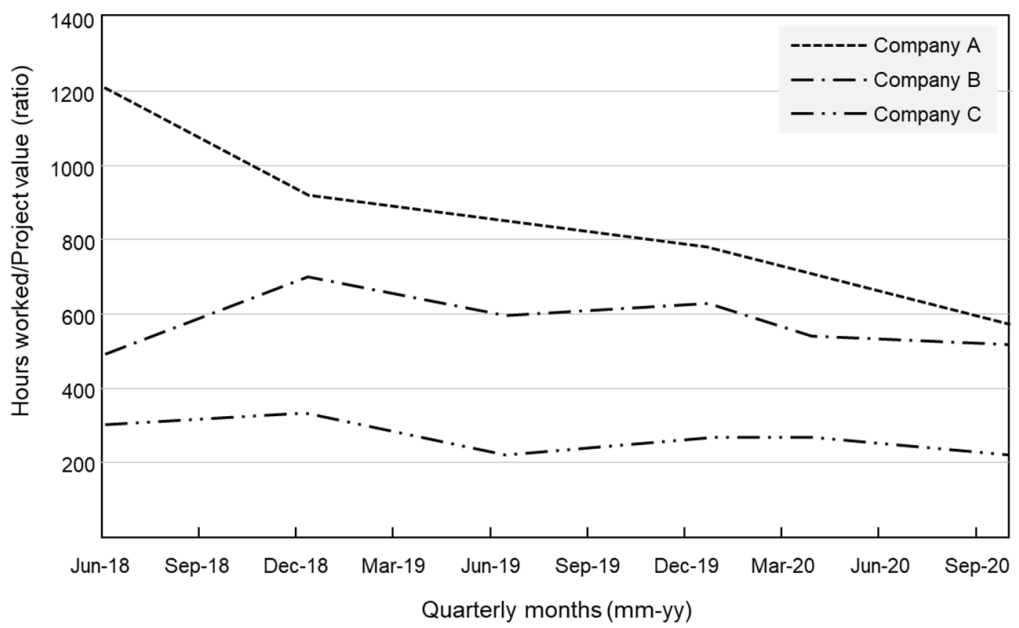

(a)

Figure 3. Cont. 


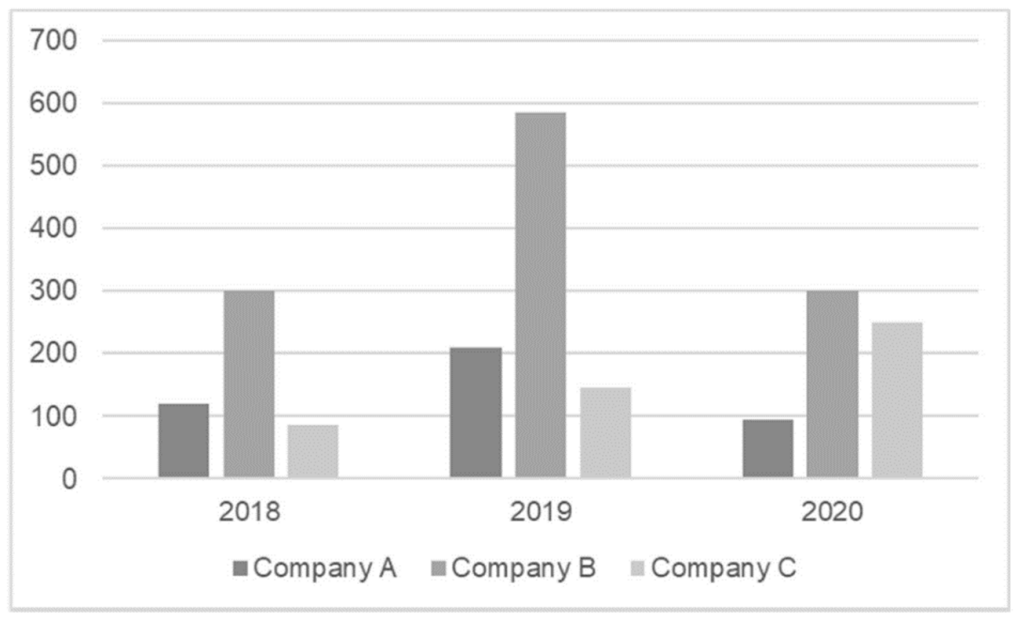

(b)

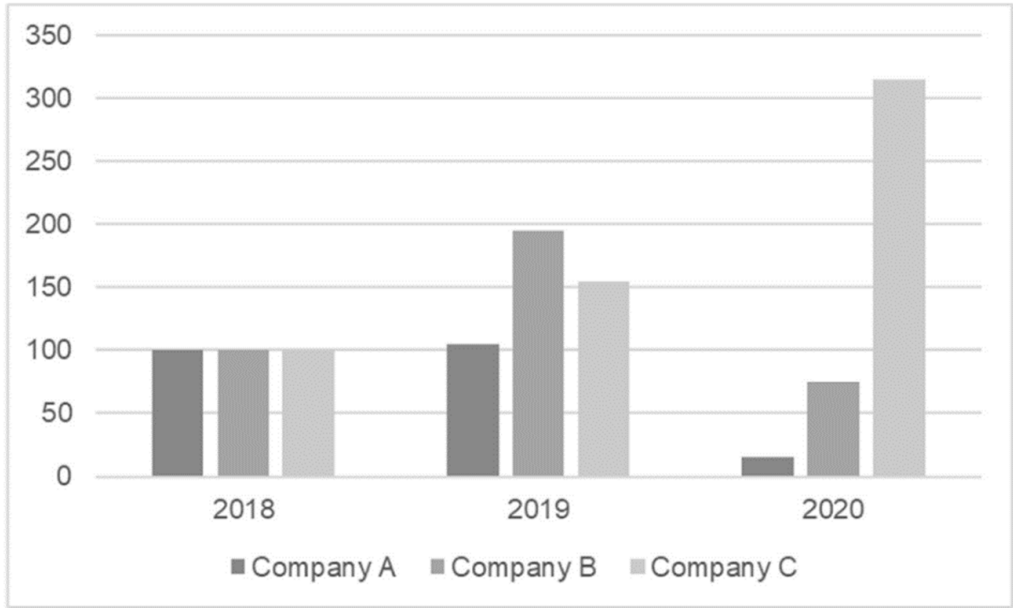

(c)

Figure 3. Fluctuations of the three values: (a) man hours/project value over financial quarters; (b) individual yearly man hours per project value over last three years; (c) project values per each company over last three years $(\%)$.

\subsection{Relative Project Efficiency over Time}

Comparing a project's value and the days taken to complete it provides insight into the work's time value. In the same way that a factory worker is assessed for their hourly output, this compared the amount of time to complete a project and monetary value of its productivity.

Company A shows decreasing behavior over the entirety of the graph in Figure 4, demonstrating a steady, then drastic, decline since the start of 2018. The lowest productivity was consistent with 2020. Company B similarly showed an overall decline, since the start of 2019; however, in 2020, the decline in productivity diminished slightly. Company C's productivity steadily rose from mid-2019, with a slight stall in the first three months of 2020 . This period did not coincide with the restrictions, given that they were not announced until after March. However, the findings could be indicative of the economy's response to the crisis. Company B demonstrated no significant impact on the amount of time in days dedicated to completing projects. Company A showed a change in 2020 that began in December 2019, while Company C presented a contrary fluctuation, increasing in March 2021. 


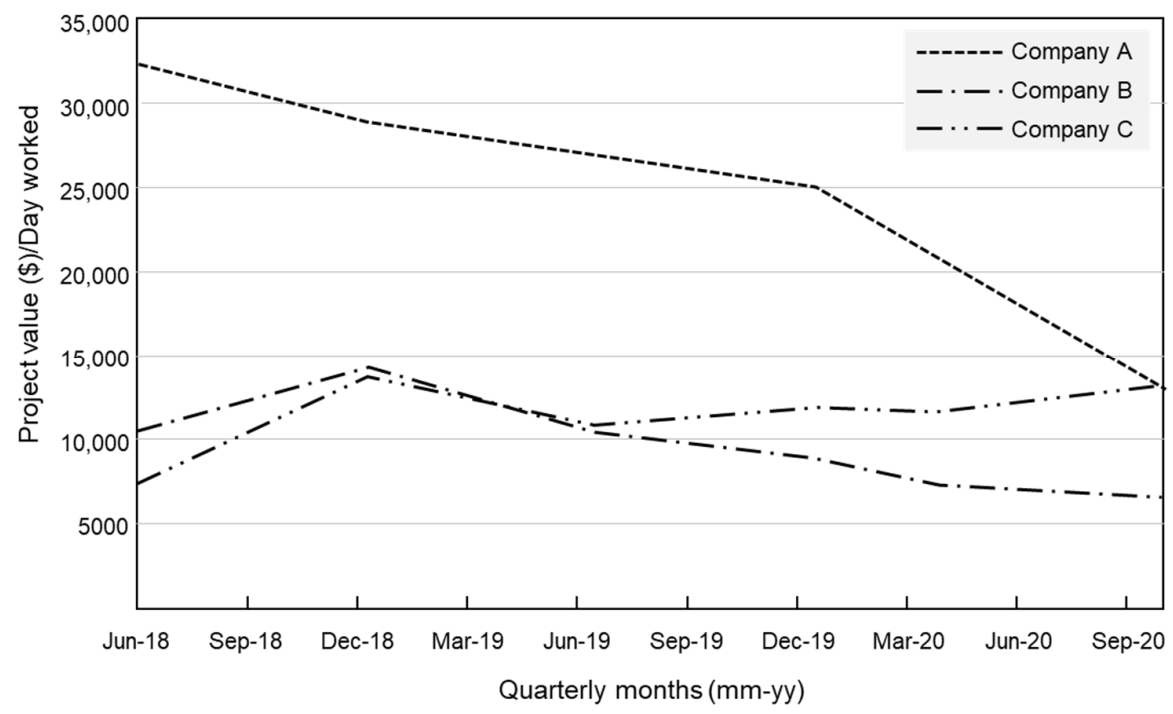

Figure 4. Project value/days worked over the financial quarters.

\subsection{Fiscal Gain Per Project}

(1) Profit by project value

Company A demonstrated consistency in the amount of profit gained per project (Figure 5). A minor dip in the first financial quarter was likely attributed to a fluctuation in steel prices, due to the global socioeconomic status and corrected itself throughout 2020. Companies $\mathrm{B}$ and $\mathrm{C}$ demonstrated similar previous behavior, with a drop in profitability at every year-end. In company B, no result was seen in 2020, other than that exhibited in previous years. However, Company $\mathrm{C}$ showed more substantial profitability, explained by its significant involvement in a large tier 1 (T1) government contract, far more extensive than previously conducted. This T1 contract was planned before the COVID-19 outbreak. Figure 5 shows no impact on profitability, due to COVID-19-related restrictions. Of course, this finding does not mean that the companies generated the same overall income as in previous years, but it does show that profit margins remained consistent for the current project, and increases were justifiably expected for new larger-scale work. In particular, Company C did not experience a drop in profit at the end of 2019, presumably due to its contract for the T1 government project.

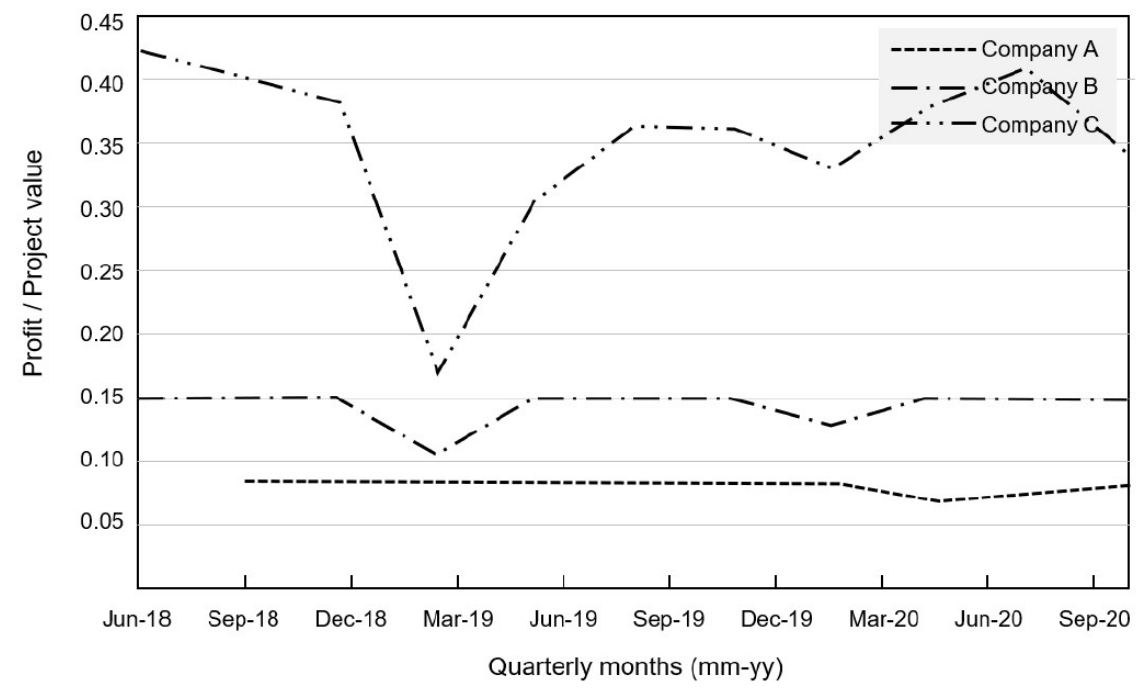

Figure 5. Profit/project value over the quarterly periods. 


\section{(2) Profit by man-hour}

It has been established that profitability over an entire project was unaffected, but this does not include other factors, such as financial productivity over time (whether profitability per person-hour changed during 2020). Company A was on a consistent downward trajectory, unchanged in 2020 (Figure 6). Company B fluctuated in 2019 but demonstrated similar behavior to Company A overall, i.e., a downward trajectory. However, company B was not significantly affected during the pandemic. In contrast, company C showed interesting behavior, demonstrating a yearly cycle. There was a significant decrease in profitability per person-hour at each year-end, but this could be a seasonal fluctuation, as it was consistent every year. Unfortunately, this result was inconclusive, in terms of assessing effects due to the pandemic. In other years, assessment could be made on the year's pattern; however, in 2020, a new contract secured by the company was a critical, unexpected influence.

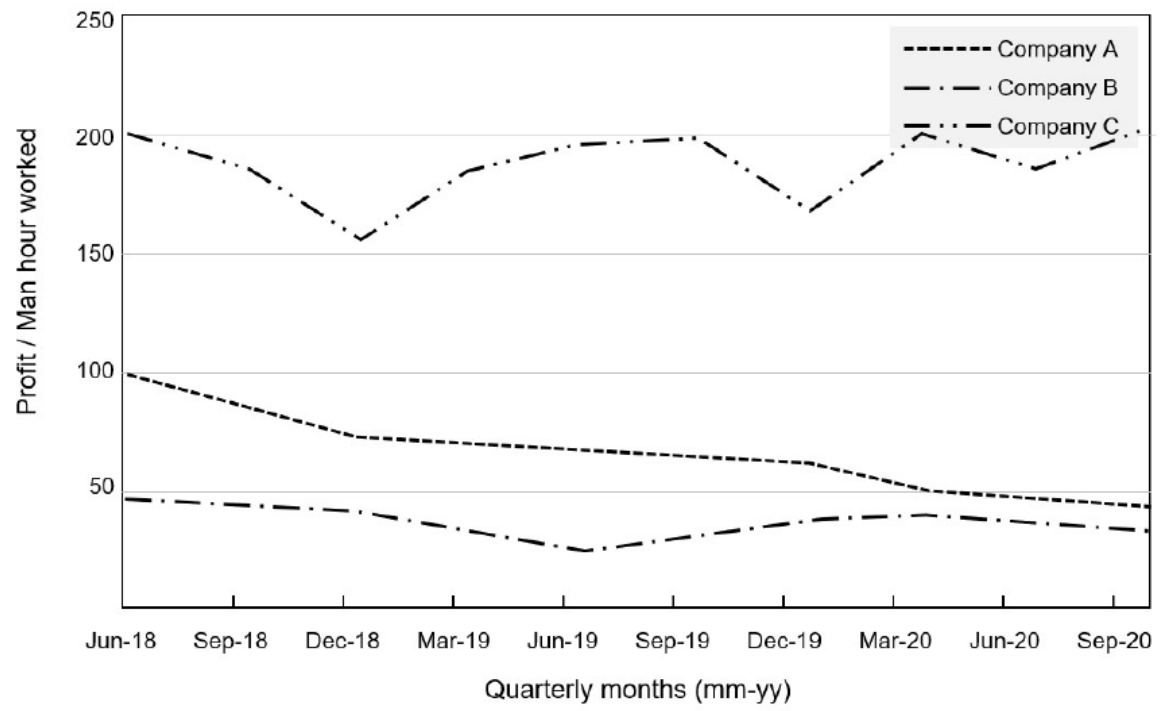

Figure 6. Profit/man-hour over the quarterly periods.

\section{Quarterly Income Comparison and Interviews}

The assessment of production factors in Section 4 yielded conclusive results, indicating that no specific effect was seen due to the pandemic. However, as previously mentioned, COVID-19 severely impacted the construction sector's GDP. Therefore, this section is dedicated to comparing total income per financial period, necessary to examine how the companies managed in 2020, compared to previous years. Unlike the previous analysis, each company was evaluated separately.

\subsection{Individual Discussion and Interview with Company $A$}

As shown in Figure 7, the years used as a baseline (2018 and 2019) demonstrate the typical behavior of Company A. Throughout the second and third quarters, company A experienced a lull in business activity, with a strong finish every year to set the company up for the following year. The company started 2020 well, with the previous year's labor dividends, and performed similarly to previous years. However, the lull was slightly more severe than other years and could be attributed to many factors. Consistency was observed in the second quarter, but an undeniable drop in expected income was seen in the third quarter, compared with the company's behavior in previous years. Figure 7 shows company A's overall behavior over time, including a forecasted result for the end of the year. These graphs clearly show a drop in the overall work completed in 2020, as the director explained in October, "Right now, the workload has diminished, and we are operating on about $50 \%$ of the typical turnover of previous financial years". Regarding the future forecast, the director went on to say, "Where the customer is an essential service or 
food-based company, some projects that have been placed on hold will recommence. It is my personal presumption that projects that have larger capital expenditure will be delayed until the companies recover to a more stable financial position. A lot of the smaller projects are comparatively low expenditures. We have many small projects in a backlog with high labor content but low profitability. We have not turned anyone away in recent months". This company will begin 2021 with a diminished bankroll and low-profit work accepted out of desperation. Altogether, these findings indicate that the most significant effect in this business may not yet be seen until next year.

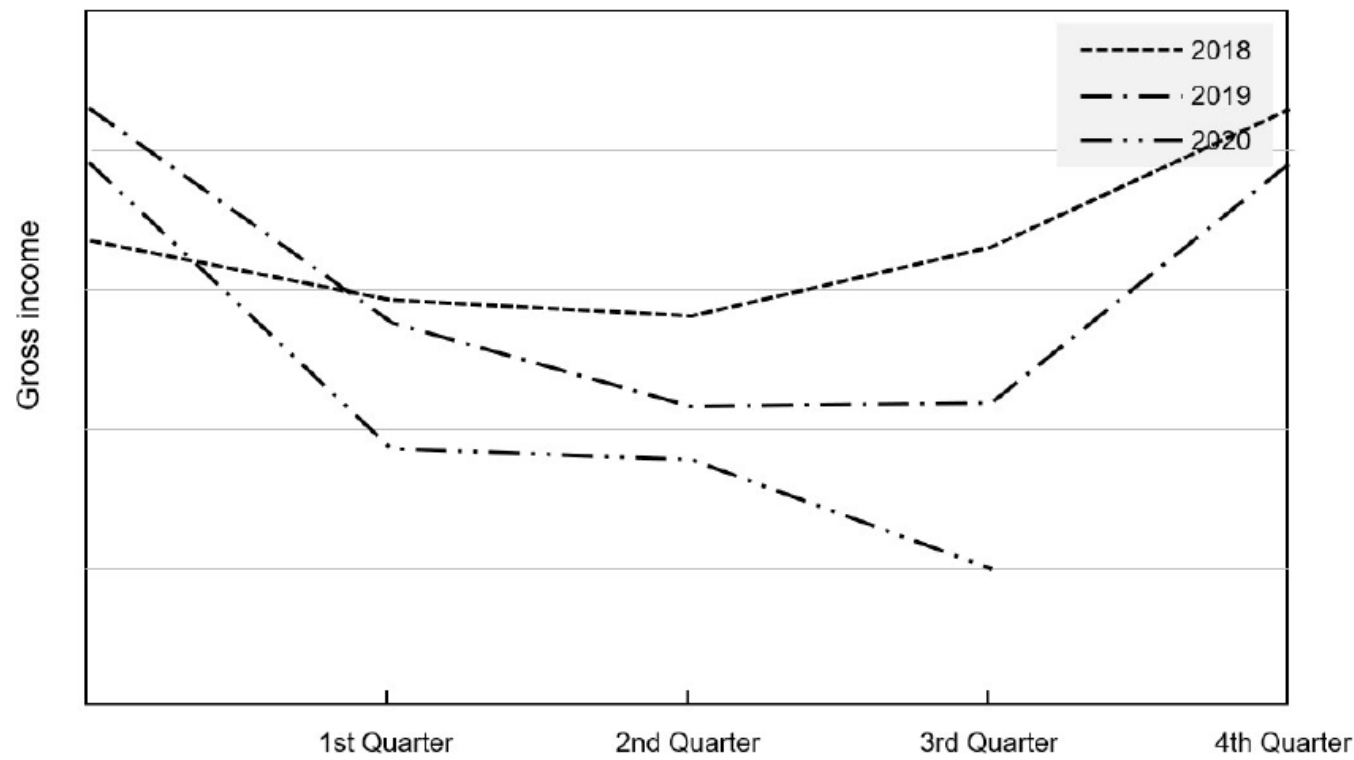

Figure 7. Company A's quarterly income comparison, as individual years (relative values only, by confidential issue).

\subsection{Individual Discussion and Interview with Company $B$}

Figure 8 shows almost identical behavior to Figure 7, in the decline of income during the year. The company finished 2019 well but faced a significant income slump in the first quarter of 2020 and experienced a minute upward trend during the second quarter. This behavior demonstrated better performance than previous years, indicating that the government restrictions at Stages 1-3 had little impact on the business. However, a tendency to underperform was observed during Stage 4 restrictions, similar to the start of the year. The director explained some of this behavior: it was "due to customer confidence given the crisis that coronavirus has brought about economically and socially, and also government restrictions on activity regarding new projects starting, and the activity of our customers' clientele. Many being retail-based, their market has been impacted, which is then seen in ours". Therefore, the impacts were explained in different ways. The first was global and local economic impact, due to worldwide panic and logistical changes. The main classification of company B's work, such as installations in factories and warehouses, could not be done while these sites were operating with staff. Similarly, with other businesses in "hibernation," companies were not eager to invest in new projects, while effectively closed. With no new projects starting, overall income declined. Finally, an indirect, but noteworthy, impact was the consequence of non-essential business closures. Although Company B did not work directly with many closed sectors, those they did service were significantly affected by the pandemic, resulting in a lack of spending. 


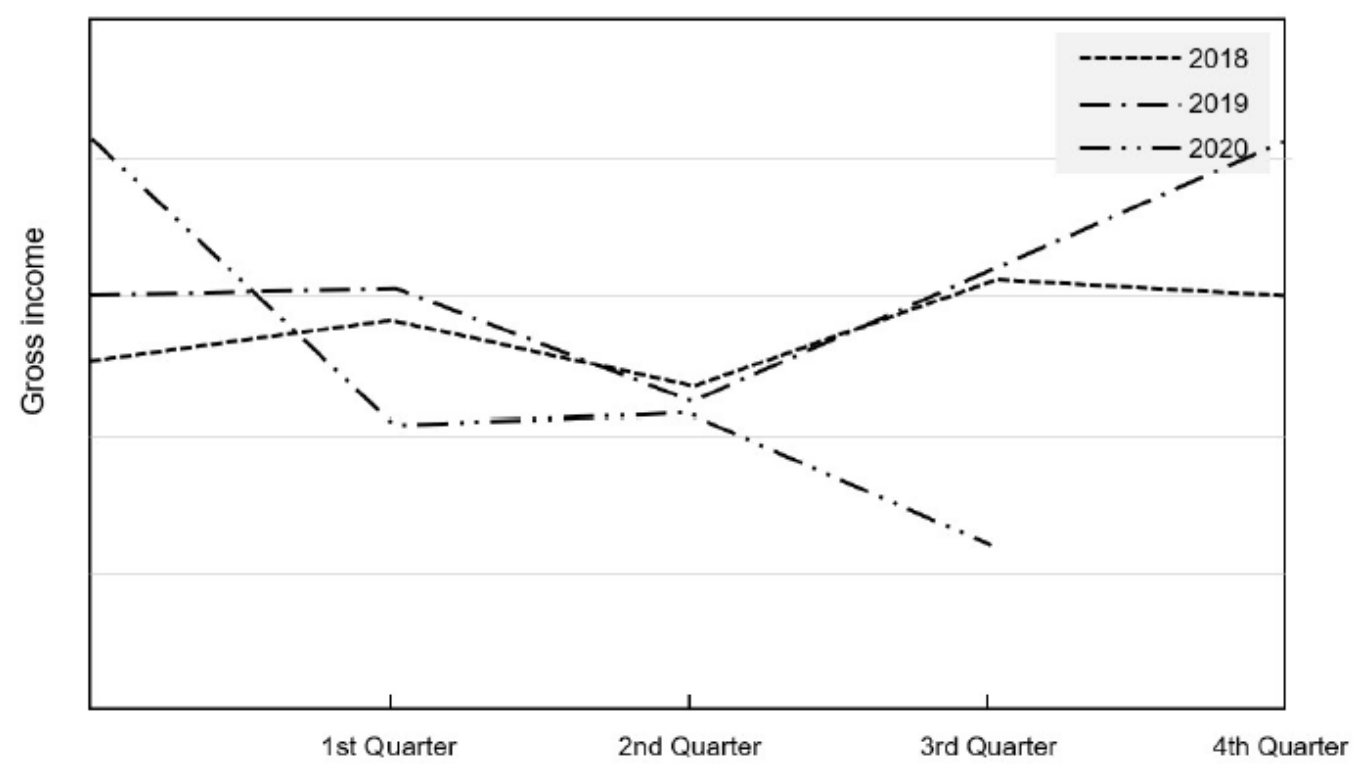

Figure 8. Company B's quarterly income comparison, as individual years (relative values only, by confidential issue).

The future expected workload was discussed with the director of Company B, when developing the forecast for the next quarter (Figure 8). The director stated, "I do not believe there will be a backlog of work concerning significant contracts or projects for major works, as the available money for capital expenditure has been greatly reduced for everyone. Our opposition in Sydney (Australia) is actually experiencing an increase in work to a degree, as the number of businesses closing has meant a surge in the removal and sale of warehousing and factory equipment".

Similar to company A, this company faced a dire situation in early 2021, as few standard projects have been confirmed. This situation is unlikely to change until the company's clients have recovered. By the director's testimony, most available work is of low profit, when the company desperately needs to increase turnover. However, the director pointed out that a similar business in Sydney reportedly had increased work, indicating that a further study, comparing companies of similar activity, is required. The differences between Company B and its competition in Sydney could compare Victorian production performance against performance in other states, reflecting changes in the economy. Global and local markets, affecting overall business, raises questions that this study cannot answer.

\subsection{Individual Discussion and Interview with Company C}

Comparatively, company C improved its production performance in 2020, as seen in Figure 9. Income increased for the first half of the year, with a steep decline in the third quarter, dropping income to a lower point than seen in previous years. In 2020, this company worked on a larger and more profitable contract than any it was involved in before. A T1 government contract resulted in unprecedented growth for the first half of the year and significant improvement. 


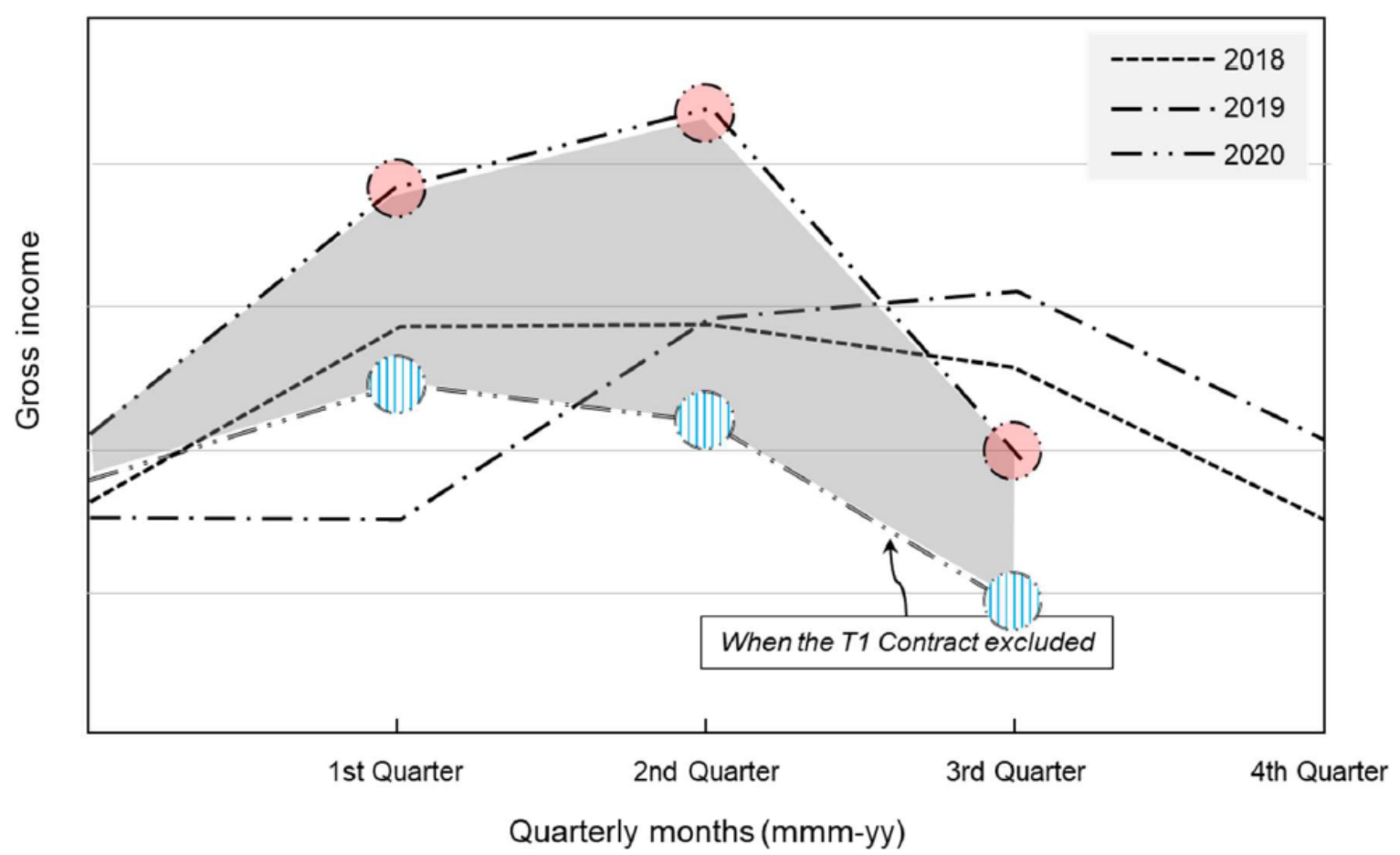

Figure 9. Company C's quarterly income comparison, as individual years, with a breakdown of the impact by the T1 government project (relative values only, by confidential issue).

However, the final months of the data (August-September) yielded that the incremental payments had significantly decreased, compared to previous months. Comparing this behavior to the curve, excluding the income from this one project, it is evident that the company's performance would have been impacted, as was observed in the other companies. In June, the director stated: "We had a large job at censored ... but that has now almost finished so the effect of the outbreak will be felt most over the next 3-6 months ... When the isolation was announced, our phones stopped ringing for residential work. We had a large bank of work ahead of us, but this now has been soaked up. I expect us to be much quieter in the next 3-4 months until things pick up again, hopefully coming into the spring to summer seasons. Our bored-piers division is now becoming quiet as many smaller residential apartment buildings have been put on hold ... as previously stated, our workload and pipeline have severely diminished, particularly in bored piers and underpinning. I would expect we may eventually have to reduce our workforce accordingly".

The main contribution to company C's production in 2020 was the T1 government contract. As seen by the greyed area in Figure 9, this contract was the only reason that Company $\mathrm{C}$ was able to hold out their income increase. Demonstrating the company's income, without this single contract, shows a year's trend consistent with companies A and $B$, i.e., a significant decline in income. The three striped points in the figure indicate this inevitable decline consistently from the first quarter to the third.

The conclusion can be drawn that government work, considered essential and high priority, provides reliability and consistency, even during this challenging time. As reported by staff at company $\mathrm{C}$, a yearly low was observed, due to the company's approximately three-week shutdown over the new year. The company must achieve its expected yearly minimum income approaching 2021, as the future does not look certain if it faces a similar slump at the end of this quarter.

\section{Research Findings and Limitations}

The analysis outcomes presented two distinct patterns between the relative and absolute value analyses in previous sections. First, the relative value analysis, with ratio indexes, did not reveal any impact of the COVID-19 pandemic. However, the absolute values, the 
quarterly income comparison, showed that all three companies in Victoria experienced a dramatic decline in 2020. The inevitable shrinkage of the general economy accounted for this result. For example, Company B endeavored to maintain its profit-person-hour ratio, as high as 30-40 in the second and third quarters of 2020 (Figure 6), by diminishing total person-hours. However, its quarterly income, during that time, showed a noticeable downward trend (Figure 8).

A large tier 1 (T1) contract provided a temporary recovery to the downward trend of company C's income, when comparing 2018-2020. The graph in Figure 9 showed improved performance in the second quarter of 2020, contributed by the company's T1 government contract. However, when this single contract was excluded from the analysis, company income performance showed a pronounced downturn, compared to the two previous years.

The greyed area in the figure depicts this temporary alleviation on company C's income in 2020. An unusual pattern also emerged, indicating a significant drop from the second to the third quarter. When the T1 government contract is excluded, the three striped points in the figure show a downward trend, indicating that the transitory recovery in mid-2020 was ephemeral and unstable. While the second and third quarters of 20182019 recorded higher income than the first and fourth quarters, the COVID-19 lockdown instigated a downturn after the first quarter of 2020, when the T1 contract was excluded.

The pandemic-related restrictions temporarily facilitated increased efficiency for the essential sectors able to continue operating during the lockdowns, but eventually bought about an unavoidable depression indirectly affecting the closed sectors. Notably, the impact of this "selective closure" measure became more evident in large projects with significant numbers of stakeholders. The findings showed that the business closures had a greater impact on the SMEs relying on large contracts for their net profit. In addition, construction continued to operate, but government restrictions were a crucial obstacle to launching new projects during the year. This obstacle affected the study's companies, as SMEs generally undertake short-term projects, rather than long-term and megaprojects.

One of the novel findings of this project was that the different indexes resulted in remarkably varied outcomes. For example, the monetary value of works did not significantly impact the three companies' performance, while the quarterly income analysis showed severe downturns for all three companies. There is a need for further research, with a larger number of companies, enabling the reliability of these findings to be confirmed. In addition, further interstate and international comparisons are suggested as future work.

\section{Summary and Conclusions}

Australia is facing an unprecedented challenge, similar to many other countries. The response to the COVID-19 crisis was intended to ensure public health and safety, with minimal impact on necessary industries. However, Victoria suffered from two waves of infection in March and July 2020. In 2021, Victoria and many other areas are still suffering the effects of the pandemic, and Victoria imposed the world's longest lockdown. More importantly, many industries remain affected, resulting in a massive economic blow. Moreover, Victoria experienced a similar crisis in July and August 2021. At the time of writing, in early 2022, the omicron variant has caused another crisis by reaching 6272 new cases locally, between 29 January 2022 and 4 February 2022 [49].

The intention of the government's response to the crisis was to ensure public health and safety, with minimal impact on essential industries. To understand the degree to which essential business was impacted, however, it is necessary to ascertain whether the response to combat public transmission of the infection was successful, from the perspectives of both public health and essential industries. The main advantages of this study lie in the data gathered from affected companies, as well as the findings uncovered by this practical approach. One of the key findings from this analysis is the different effects seen at the level of individual projects or organizations. This means that the impact on individual workers in construction projects was not significant. Although the attitude towards the restrictions in the industry was that they significantly stunted on-site productivity, this is not necessarily 
the case for small-scale projects and individual workers. On a project-to-project basis, it was reported that workers performed almost identically as they had in previous years. Given this, the conclusion can be drawn that stage 4 restrictions should only be implemented reluctantly, as they would cause a severe impact on industries such as construction.

Conversely, overall organizational income was significantly impacted from a wholistic perspective. The companies saw quite severe fiscal impacts, due to a diminished level of productivity. The companies struggled to maintain the level of work that they would normally expect to see, prior to the stage 1 restrictions. A direct impact was identified that correlated with the stage 4 restrictions. These restrictions limited construction to servicing only essential infrastructure or businesses, and this caused a drop in gross income, following the second financial quarter.

There was a further drop in the companies' gross income that is not attributable to any restrictions, as it preceded their implementation. This was caused by the global economy responding to the international health crisis. An unexpected ripple effect was observed in the level of projects being commissioned in the construction sector in Victoria. This may indicate that the government restrictions caused minimal, if any, effect on the productivity of small-scale construction, so any changes were inherent in the needs of a disrupted market. In addition, the results of this study imply that individual companies experienced the pandemic differently. Therefore, the operational level of individual companies should be considered separately when developing financial support measures to assist businesses affected by COVID-19.

Victoria is not the most severely damaged region but has experienced an extremely high level of restrictions and the longest lockdown imposed during this pandemic crisis. Given the distinct situation in Victoria, the implications of this study could help Victoria in the coming days by providing the impact on the individual company level. The quantified evidence in the study also represents the actual troubles that ordinary SMEs are experiencing. Future work could involve studying the different situation in Sydney, New South Wales, as suggested by company B's director. Analysis of interstate or international data could further explain the impact of COVID-19 on the performance and productivity of the construction industry.

Author Contributions: Data curation, J.B.; Formal analysis, H.C. and M.C.; Investigation, H.C. and M.C.; Methodology, J.B.; Supervision, S.M.; Writing - original draft, J.B., H.C. and M.C.; Writingreview \& editing, S.M. All authors have read and agreed to the published version of the manuscript.

Funding: This project is a part of an ongoing project: "Innovation in Construction Automation \& Technologies" supported by the Australian Government through the Australia-Korea Foundation of the Department of Foreign Affairs and Trade. (Grant number: AKF2018003).

Institutional Review Board Statement: Not applicable.

Informed Consent Statement: Informed consent was obtained from all subjects involved in the study.

Data Availability Statement: Data available on request to the corresponding author.

Conflicts of Interest: The authors declare no conflict of interest.

\section{References}

1. World Health Organization. Novel Coronavirus (2019-nCoV) Situation Report-22 February 2020. Available online: https:/ /ww w.who.int/docs / default-source/coronaviruse/situation-reports/20200222-sitrep-33-covid-19.pdf?sfvrsn=c9585c8f_4 (accessed on 9 January 2022).

2. Australian Bureau of Statistics. Building Approvals, Australia; Key Economic Indicators. Available online: https://www.abs.gov. $\mathrm{au} /$ statistics/economy/key-indicators (accessed on 9 January 2022).

3. Leviäkangas, P.; Paik, S.M.; Moon, S. Keeping up with the pace of digitization: The case of the Australian construction industry. Technol. Soc. 2017, 50, 33-43. [CrossRef]

4. Victoria State Government. COVID-19 Chief Health Officer Update. Available online: https://www.health.vic.gov.au/covid-19 / covid-19-chief-health-officer-update (accessed on 9 January 2022). 
5. Butt, C. Ten Graphs That Show the Rise and Fall of Victoria's COVID-19 Second Wave. The Age. October 2020. Available online: https:/ / www.theage.com.au/national/victoria/ten-graphs-that-show-the-rise-and-fall-of-victoria-s-covid-19-second -wave-20201027-p5694b.html (accessed on 9 January 2022).

6. Health and Human Services, Victoria State Government. Coronavirus Update for Victoria-5 August 2020. Available online: https:/ / www.dhhs.vic.gov.au/coronavirus-update-victoria-5-august-2020 (accessed on 9 January 2022).

7. Bleby, M. Construction Sheds \$14 Billion Since March. The Australian Financial Review. 2020. Available online: https://www.afr.co $\mathrm{m}$ / property/commercial/construction-sheds-14-billion-since-march-20200519-p54ukk (accessed on 9 January 2022).

8. Mckenzie, B. Potential Australian Govt Shut Down of Construction Sites Due to Coronavirus: Legal Considerations. 2020 Available online: https://www.bakermckenzie.com/en/insight/publications/2020/04/australian-govt-shut-down-of-const ruction-sites (accessed on 9 January 2022).

9. Work Safe Victoria. COVID-19: Information for Employees. Available online: https://www.worksafe.vic.gov.au/information-em ployees-coronavirus-covid-19 (accessed on 9 January 2022).

10. Direct Health Solutions Pty Ltd. Managing Absenteeism during a Pandemic. Available online: https://www.dhs.net.au/news/ managing-absenteeism-during-a-pandemic (accessed on 9 January 2022).

11. Rivera, K. Dependence on Construction Can Cause Housing Correction. 2019. Available online: https://www.yourinvestmentpr opertymag.com.au/news/dependence-on-construction-can-cause-housing-correction-261305.aspx (accessed on 9 January 2022).

12. Premier of Victoria The Hon D. Andrews. Statement on Changes To Melbourne's Restrictions. August 2020. Available online: https:/ / www.premier.vic.gov.au/statement-changes-melbournes-restrictions (accessed on 9 January 2022).

13. Wahlquist, C. Melbourne under Curfew as Daniel Andrews Extends Lockdown by Two Weeks. The Guardian. 2021. Available online: https://www.theguardian.com/australia-news/2021/aug/16/victoria-covid-update-melbourne-under-curfew-as-d aniel-andrews-extends-lockdown-by-two-weeks (accessed on 9 January 2022).

14. Silva, K. VicHealth Survey Reveals Victorians' Eating Habits Improved during Coronavirus Lockdown, While Mental Health Suffered. ABC News. 2020. Available online: https: / /www.abc.net.au/news/2020-12-10/victorians-less-satisfied-with-life-covi d-mental-health-survey/12966868 (accessed on 9 January 2022).

15. Public Health and Wellbeing Act 2008; Extension of Declaration of a State of Emergency. 2020. Available online: https: / / www.dhhs.vic.gov.au/sites/default/files/documents/202110/State\%20of\%20Emergency\%20Extension \%20-\%2 021\%20October\%202021.pdf (accessed on 9 January 2022).

16. Service Victoria, Coronavirus (COVID-19). Available online: https: / service.vic.gov.au/covid-19 (accessed on 9 January 2022).

17. Beck, M.J.; Hensher, D.A. Insights into the Impact of COVID-19 on Household Travel and Activities in Australia-The Early Days of Easing Restrictions. Transp. Policy 2020, 99, 95-119. [CrossRef] [PubMed]

18. Reserve Bank of Australia. Supporting the Economy and Financial System in Response to COVID-19. Available online: https:/ / www.rba.gov.au/covid-19 (accessed on 9 January 2022).

19. Prime Minister, Treasurer. Media Release: Economic Stimulus Package. March 2020. Available online: https://www.dhhs.vic.gov .au/sites/default/files/documents/202110/State\%20of\%20Emergency\%20Extension\%20-\%2021\%20October\%202021.pdf (accessed on 9 January 2022).

20. Grattan, M. Government's New \$66 Billion Package will Take Coronavirus Economic Life Support to \$189 Billion. The Conversation. March 2020. Available online: https:/ / theconversation.com/governments-new-66-billion-package-will-take-coronavirus-e conomic-life-support-to-189-billion-134331 (accessed on 9 January 2022).

21. Prime Minister of Australia. Update on Coronavirus Measures. 2020. Available online: https://www.pm.gov.au/ (accessed on 9 January 2022).

22. Victoria Reimposes Coronavirus Stage 3 Lockdown on Metropolitan Melbourne and Mitchell Shire after Record Rise in Cases. ABC News. 2020. Available online: https://www.abc.net.au/news/2020-07-07/victoria-reimposes-lockdown-as-coronavirus-ca ses-rise/12429990 (accessed on 9 January 2022).

23. Victoria State Government. Victorian COVID-19 Data. Available online: https://www.coronavirus.vic.gov.au/victorian-coronav irus-covid-19-data (accessed on 9 January 2022).

24. Master Builders Victoria. Building and Construction Remains an 'Essential Service'. Master Builders Victoria. 2020. Available online: https://www.mbav.com.au/news-information/news/economyfinance/building-and-construction-remains-essential -service? economyfinance (accessed on 9 January 2022).

25. Working outside Home during Melbourne's Stage 4 Coronavirus Restrictions Will Require a Permit. Here's What We Know about Them. ABC News. 2020. Available online: https://www.abc.net.au/news/2020-08-04/ coronavirus-worker-permit-victoria-stage4-lockdown-explained/12521368 (accessed on 9 January 2022).

26. Health and Human Services, Victoria State Government. Statement from the Premier. 6 September 2020. Available online: https: / / www.premier.vic.gov.au/sites/default/files/2020-09/200906\%20-\%20Statement\%20From\%20The\%20Premier.pdf (accessed on 9 January 2022).

27. Health and Human Services, Victoria State Government. Coronavirus (COVID-19) Daily Update. Victoria State Government. Available online: https:/ / www.health.vic.gov.au/covid-19/latest-news-and-data-covid-19 (accessed on 9 January 2022).

28. Department of Health, Australian Government. COVID-19 Omicron Variant. January 2022. Available online: https: //www.health.gov.au/health-alerts/covid-19/symptoms-and-variants/omicron\#: \{\}:text=The\%20Omcron\%20COVID\%2D19 \%20variant,evidence \%20that \%20it\%20spreads\%20quickly (accessed on 9 January 2022). 
29. Cunningham, M.; Dow, A. Daily Struggle to Fill Shifts in Victoria's Hospitals as Omicron Bites. The Age. 2022. Available online: https:/ / www.theage.com.au/national/victoria/daily-struggle-to-fill-shifts-in-victoria-s-hospitals-as-omicron-bites20220107-p59mj1.html (accessed on 9 January 2022).

30. Halpin, D.W. Construction Management; John Wiley \& Sons: Hoboken, NJ, USA, 2010.

31. Moon, S.; Zekavat, P.; Bernold, L.E. Dynamic control of construction supply chain to improve labor performance. J. Constr. Eng. Manag. 2015, 141, 05015002. [CrossRef]

32. Wang, W.; Fu, Y.; Gao, J.; Shang, K.; Gao, S.; Xing, J.; Ni, G.; Yuan, Z.; Qiao, Y.; Mi, L. How the COVID-19 Outbreak Affected Organizational Citizenship Behavior in Emergency Construction Megaprojects: Case Study from Two Emergency Hospital Projects in Wuhan, China. J. Manag. Eng. 2021, 37, 04021008. [CrossRef]

33. Tan, T.; Mills, G.; Hu, J.; Papadonikolaki, E. Integrated Approaches to Design for Manufacture and Assembly: A Case Study of Huoshenshan Hospital to Combat COVID-19 in Wuhan, China. J. Manag. Eng. 2021, 37, 05021007. [CrossRef]

34. Assaad, R.; El-adaway, I.H. Guidelines for Responding to COVID-19 Pandemic: Best Practices, Impacts, and Future Research Directions. J. Manag. Eng. 2021, 37, 06021001. [CrossRef]

35. Alsharef, A.; Banerjee, S.; Uddin, S.; Albert, A.; Jaselskis, E. Early impacts of the COVID-19 pandemic on the United States construction industry. Int. J. Environ. Res. Public Health 2021, 18, 1559. [CrossRef] [PubMed]

36. Choi, C.-Y.; Ryu, K.R.; Shahandashti, M. Predicting City-Level Construction Cost Index Using Linear Forecasting Models. J. Constr. Eng. Manag. 2021, 147, 04020158. [CrossRef]

37. Kim, S.; Kong, M.; Choi, J.; Han, S.; Baek, H.; Hong, T. Feasibility analysis of COVID-19 response guidelines at construction sites in south korea using CYCLONE in terms of cost and time. J. Manag. Eng. 2021, 37, 04021048. [CrossRef]

38. Hasan, A.; Rameezdeen, R.; Baroudi, B.; Ahn, S. Mobile ICT-Induced Informal Work in the Construction Industry: Boundary Management Approaches and Consequences. J. Constr. Eng. Manag. 2021, 147, 04021109. [CrossRef]

39. Pirzadeh, P.; Lingard, H. Working from Home during the COVID-19 Pandemic: Health and Well-Being of Project-Based Construction Workers. J. Constr. Eng. Manag. 2021, 147, 04021048. [CrossRef]

40. Kraus, S.; Clauss, T.; Breier, M.; Gast, J.; Zardini, A.; Tiberius, V. The economics of COVID-19: Initial empirical evidence on how family firms in five European countries cope with the corona crisis. Int. J. Entrep. Behav. Res. 2020, 26, 1067-1092. [CrossRef]

41. Eisenhardt, K.M. Building theories from case study research. Acad. Manag. Rev. 1989, 14, 532-550. [CrossRef]

42. Vaughan, D. Beyond macro-and micro-levels of analysis, organizations, and the cultural fix. In International Handbook of WhiteCollar and Corporate Crime; Springer: Berlin/Heidelberg, Germany, 2007; pp. 3-24.

43. Jarkas, A.M. The impacts of buildability factors on formwork labour productivity of columns. J. Civ. Eng. Manag. 2010, 16, 471-483. [CrossRef]

44. Ham, N.; Moon, S.; Kim, J.-H.; Kim, J.-J. Economic analysis of design errors in BIM-based high-rise construction projects: Case study of Haeundae L project. J. Constr. Eng. Manag. 2018, 144, 05018006. [CrossRef]

45. Harrison, H.; Birks, M.; Franklin, R.; Mills, J. Case study research: Foundations and methodological orientations. Forum Qual. Soz./Forum Qual. Soc. Res. 2017, 18, 1-17.

46. Gourinchas, P.-O.; Kalemli-Özcan, Ṣ.; Penciakova, V.; Sander, N. COVID-19 and SME Failures; National Bureau of Economic Research: Cambridge, MA, USA, 2020.

47. Australian Bureau of Statistics. Counts of Australian Businesses, Including Entries and Exits. 2021. Available online: https:/ / www.abs.gov.au/statistics/economy/business-indicators/counts-australian-businesses-including-entries-and-exits /latest-release\#: \{\}:text=At\%20June \%2030\%202021\%20there,businesses\%20in\%20the\%20Australian\%20economy.\&text=3.8\% 25\%2C \%20or $\% 2087 \% 2 \mathrm{C} 806 \% 2 \mathrm{C} \% 20$ increase, exit $\% 20$ rate $\% 2 \mathrm{C} \% 20$ with $\% 20277 \% 2 \mathrm{C} 674 \% 20$ exits (accessed on 9 January 2022).

48. Hou, L.; Zhao, C.; Wu, C.; Moon, S.; Wang, X. Discrete firefly algorithm for scaffolding construction scheduling. J. Comput. Civ. Eng. 2017, 31, 04016064. [CrossRef]

49. Department of Health, Australian Government. Coronavirus (COVID-19) Case Numbers and Statistics. Available online: https:/ / www.health.gov.au/health-alerts/covid-19/case-numbers-and-statistics (accessed on 9 January 2022). 